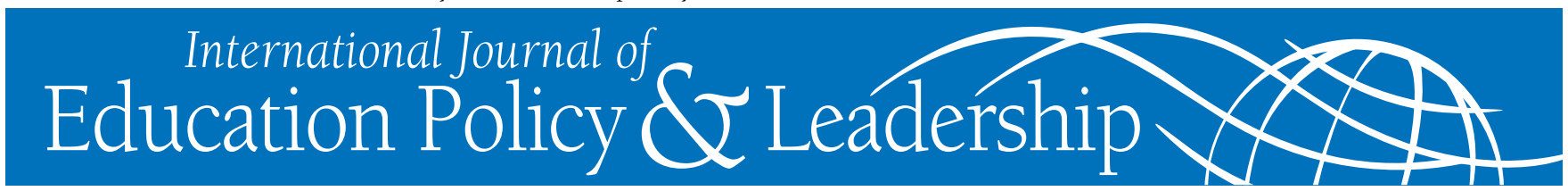

\title{
Information and Communication Technologies in International Education: A Canadian Policy Analysis
}

\author{
ROBERT C. AuCOIN \\ Avant Learning
}

\begin{abstract}
The rhetoric surrounding the use of information and communication technologies (ICTs) in international education speaks of providing education access for all. However, an examination of actual policies reveals an emphasis not on creating an educated population, but on improving economic opportunities using discourses such as globalization, knowledge economy, and knowledge society. This emphasis creates an imbalance in opportunities for using ICTs in education and presents challenges for international educators. This paper discusses the Canadian International Development Agency's report, CIDA's Strategy on Knowledge for Development through Information and Communication Technologies, as an example of how rhetoric does not always meet reality. The paper concludes with four simple recommendations for good ICT practice in developing contexts.
\end{abstract}

Aucoin, R. (2011). Information and Communication Technologies in International Education: A Canadian Policy Analysis. International Journal of Education Policy and Leadership, 6(4).

\section{Introduction}

Nelson Mandela once said, [Education is] "the most powerful weapon which we can use in order to prepare our youth in their role as leaders of tomorrow" (Bartz, 1990). Many in international education circles have been asking questions along that line (see Freire, 1970; Hillman, 2002; Kemp \& Kojima, 1985; Sen, 1999; Yang, 2003). Is international education our best opportunity to change the world, alleviate poverty, and foster peace in developing nations? Does international education empower or disenfranchise recipient governments, education institutions, communities, or individuals? Or is international education simply a glorified form of neocolonialism, where the developed (or Western) nations impose their own education and development agenda on the recipient nations?

A positive answer to these questions would certainly place a tremendous burden on educators to solve the world's problems and is certainly not the intention of asking the questions. However, writers on development from various disciplines have often made the link between education and the alleviation of poverty (Freire, 1970; Sen, 1999). Moreover some writers have criticised development agencies for neglecting education in their development plans in favor of larger infrastructure projects, and they show that creating economic growth does not necessarily lead to the alleviation of poverty (Hillman, 2002; Sen, 1999).

These challenges have defied resolution since the dawn of international education, usually in the form of correspondence schools beginning more than 100 years ago with university extension programs. With the emergence of global knowledge economies, the advent of information and communication technologies (ICTs), and the seemingly inevitable globalization of world economies, the threats, dangers, and opportunities for international education are greater than

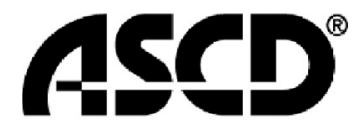

LEARN. TEACH. LEAD.
SIMON FRASER UNIVERSITY THINKING OF THE WORLD

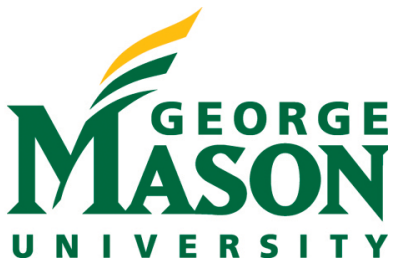


ever. Yet there is scant critical analysis of these dangers and opportunities.

This paper attempts to start a dialogue on those issues. It will examine international higher education through the lenses of globalization and knowledge economy, and it will provide an analytical framework for critiquing policies on using ICTs for education in developing nations. The particular example offered in this paper is CIDA's Strategy on Knowledge for Development through Information and Communication Technologies (Canadian International Development Agency [CIDA], 2006).

\section{International Education in the Con- text of ICTs}

Traditionally, education systems have focused on creating national communities of living and working. With the advent of ICTs, the prospect of creating international communities of living and working have further developed. ICT is a term that encompasses all technological tools used to manipulate and communicate information, such as recording media (e.g., CDs/DVDs), broadcasting systems (e.g., radio, television), computing hardware and software (e.g., World Wide Web, email), and mobile networks and devices (e.g., cell phones, smart phones). Increasingly people, money, and information cross borders to the extent that where information originates or resides is unclear. These developments, in turn, affect national education systems.

To date, many universities offer onshore, offshore, and distance learning programs (Monash University, 2007). Onshore refers to traditional, face-to-face education that is offered in the host country. Offshore, often through satellite campuses, refers to face-to-face education offered in a foreign country. Distance learning, by contrast, refers mostly to online learning, but it can also refer to education via radio; television; or other media, including correspondence courses. These programs are often delivered from a single institution to various locations.

\section{Knowledge Economy and Higher Education}

The terms knowledge economy and knowledge society are often used interchangeably, which is unfortunate because they have radically different connotations (Pe- ters, 2001; Yang, 2003). For the purposes of this article, a knowledge economy refers to the use of knowledge to generate economic benefit. Knowledge societies are much broader but often include knowledge economies (Yang, 2003). Knowledge societies refer to any knowledge-based communities, which are not new and would include ancient societies, such as Freemasons and weaving guilds from centuries ago. What is new in the ICT era is the way in which knowledge societies are no longer encumbered by geography or time in the exchange of knowledge.

Current discourses about international education focus mostly on knowledge economies rather than knowledge societies. Traditional models of economics have focused on the collection of capital, such as labor and property. But capital now includes the acquisition of knowledge, and the combination of knowledge and skills is seen as the only source of comparative advantage nations have over one another (Yang, 2003, World Bank, 1995). This becomes an issue of power because certain nations are able to use their comparative advantage over others for personal and national gain. Therefore, many developed nations now emphasize education as a vital part of the economy to create new wealth, new credentials, and new technologies (Peters, 2001). A number of education plans around the world, for example, now refer to providing greater choice in education as well as an emphasis on skillsbased learning and knowledge management (World Bank, 2007).

Discourses concerning the knowledge economy and higher education appear equally in international education. As Bacchi (2000) points out, these discourses have strong implications in the power equation between developed and developing nations. She writes, "Those who are deemed to 'hold' power are portrayed as the ones making discourse, whereas those who are seen as 'lacking' power are described as constituted in discourse" (Bacchi, 2000, p. 52).

Peters (2001) continues with four broad critiques of current discourses about knowledge economies and higher education. The first critique is that current education policies do not make distinctions between knowledge and information, nor between knowledge economy and knowledge society. Second, knowledge economy is itself ill-defined. It might mean having a certain proportion of the population employed in knowledge industries. It may equally mean that 
knowledge is now a factor of all forms of economic production. If that is the case, should education simply be seen as "a form of investment in human capital" (Peters, 2001, p. 14)? Peters's third critique is that policy discourses about the knowledge economy use the ideas of futurology, which are steeped in economic language. And, because these policies attempt to prescriptively predict the future, they do not acknowledge lessons of the past. Finally, Peters argues that there are important changes in the world of work not accounted for in current models of the knowledge economy. For example, there is an assumption that the economy will be able to absorb future knowledge workers.

Our society needs to fundamentally rethink what it means to work and, by extension, what education and schooling are. For example, perhaps an expanded definition for work is needed to mean "meaningful occupation" rather than simply "paid employment." This would have ramifications for conceptualizing education as a journey toward "the good life" and would have to include persons who choose to stay at home to raise their families. Further, it would entail rethinking what the knowledge economy means and how people interact with other societies and cultures. This is to avoid "recreating and reinforcing systematic social inequalities and exacerbating economic and social polarisation" (Chisolm, 1999, as cited in Peters, 2001, p. 3).

\section{Globalization and Higher Education}

International education has its roots in comparative education, which in turn has a history associated with education reform. Education reform has been steeped in language about "philosophical and cultural origins of national education systems" (Carnoy $\&$ Rhoten, 2002, p.1). More recently, international education has been seen through the lenses of economic and social change, including political economies, neocolonialism, and development. These ideas have coalesced around the idea of globalization.

Much of the policy issues surrounding international education are concerned with the perceived or real effects of globalization on world societies, especially developing nations. The word globalization has become a flash point for people of vastly different philosophies. Uses range from those who believe that globalization is simply the increased connectedness among peoples across the globe to those who believe that globalization is "the direct consequence of the expansion of European cultures across the world via settlement, colonialisation and cultural mimesis" (Waters, 1995, p. 3).

One concept that both sides of the globalization debate do seem to agree on is the idea that knowledge and information are drivers of globalization. It is less clear, however, whether the opposite is true. Does globalization inform or transmit knowledge and information? Carnoy and Rhoten (2002) push this question further by asking, "To what degree does educational change represent regional, national or local responses to global economic restructuring, and to what degree do these changes represent international agencies' intentions regarding these responses?" (p. 2).

Daniel (2006) argues that globalization and technology have changed little in education, even in nations most closely associated with the global economy, in that we still teach and learn the same way Isaac Newton learned. We still use those traditional paradigms. However, this only tells part of the story. In fact, national governments and education leaders fear that they will somehow be left behind if they do not embrace globalization. As a result, the discourse concerning globalization becomes more entrenched with a renewed emphasis on the notion of accountability and standards. This emphasis manifests in education systems through phenomena like standardized testing, privatization, choice, accountability, and prior learning assessment (Carnoy \& Rhoten, 2002).

The aspect of globalization that garners the most attention and the most fear is economic globalization. It is clear that, for good or bad, economic globalization has a profound effect on education. Yang (2003) argues that globalization is a negative force with respect to higher education and social institutions generally. He argues that the rapid expansion of the global higher education market is motivated by economics and greed rather than by policy. This has resulted in a renewed view of higher education, one that is economic and standards-based that emphasizes government and industry partnerships. This new view of higher education examines both the business of the university and the university as a business. In other words, education has become an economic activity. The major problem with this view, according to Yang (2003), is that higher education has become a private matter of individual 
choice. It ignores the reality that higher education is also a force for public good and deserves to be recognized as such in public policy.

In the long term, education institutions (and universities in particular) have come under such pressure to generate revenues that they have seen international expansion as the main route to survival in the globalized environment. Many Western universities, for example, have taken a step further by envisioning global higher education networks (often through satellite campuses or distance education with the use of ICTs) that will generate larger numbers of students (and revenue) without incurring comparable costs, because students would not physically be on their campuses. The rhetoric used to justify building these networks is more about access than revenue generation. Universities talk about populations in developing countries that want post-secondary education and Western credentials but, for reasons of access, are unable to meet these needs. They see distance education and ICTs as the answer to this challenge. The reality is that marketing efforts are not directed at these populations but to "hot" economies from Asia, as evidenced by the numerous international education programs in countries like China and India. By contrast, there are few such programs in countries where access really is a problem, like those in sub-Saharan Africa. This practice reinforces a belief that international education has little to do with providing access to higher education and more to do with generating revenues for Western institutions.

\section{Framing the Issues}

The lenses of both globalization and the knowledge economy raise a number of common issues with respect to international higher education. Both globalization and the knowledge economy are closely connected to ICTs, which are transforming world culture (Carnoy \& Rhoten, 2002). This transformation could mean that many groups and nations feel marginalized, and they have both become and have created counterpublics. The irony is that many of these counterpublics are themselves global, including fundamentalist religions, environmental movements, and feminist movements. As noted by Fraser (1990), these counterpublics are frequently subaltern in the sense that they are "parallel discursive arenas" (p. 67). The danger with this situation is that these different publics are unable or unwilling to talk to one another because of an inability to discern between public and private spaces as well as between global and local environments.

Another issue is the debate between public versus private and local versus global. Although global forces for change appear to be an education tsunami, they often have unintended local consequences. These consequences are usually negative and include challenges as far reaching as the global trafficking of women and relative brain drains from have-not nations to have nations. What some writers (e.g., Peters, 2001; Yang, 2003) appear to call for is a more robust debate on these issues and a greater move to decisions based on sound public policy rather than an exclusive focus on market-driven profits. There is no doubt, however, that all these issues are connected. So a debate about public, private, global, and local should be seen as facets of the same issues.

Where should higher education professionals be in this debate? Where will the effects of these debates be seen, locally, or globally? Is it philosophically more important to be publicly motivated than to be privately motivated? These types of debates will help higher education professionals decide how they will adapt to the inevitable forces for change through globalization. Furthermore, the debate will help professionals in international education avoid the colonial mistakes of the past. This debate about education must begin and remain local or, at the very least, should include local variations of global trends (Yang, 2003).

The challenges to international education remain the same regardless of the lens, knowledge economy or globalization. The threat of renewed colonialization, cultural imperialism, and global dominance all find their own manifestations within the realm of international education. Culture and language are ubiquitous issues that need to be acknowledged and embraced, rather than seen as problems to be solved. In the relatively new era of ICTs and knowledge economics, new challenges emerge in international education: providing learner support across borders, the focus on consumerism in education, the development (or breakdown) of communities, the lack of international regulation, and the creation of policies driven by global economics rather than public good or goodwill.

Although I have so far presented a mostly negative view of globalization and the knowledge economy, 
there remain many positive possibilities for higher education in developing nations. Most of the issues I raise in this paper should be seen as challenges rather than threats. The way these challenges are met will vary depending on how the issues are framed. More specifically, international education needs to become a way of providing education access to those who really need it. The goal is to prevent the less savory aspects of globalization from using international education and ICTs as a conduit to neocolonialism.

\section{Policy Analysis: An Example}

After framing the issues, it is worth the effort to analyze a real policy and examine it under the lenses provided in this paper. Canada's primary development agency, the Canadian International Development Agency (CIDA) offers such an opportunity. In 2006, CIDA published its strategy paper on ICTs, titled CIDA's Strategy on Knowledge for Development through Information and Communication Technologies. It outlines the Canadian government's plan to use ICTs as a development tool in various sectors, including health and education (CIDA, 2006).

\section{Canada's Approach to Development Through ICTs}

CIDA is funded by the federal government of Canada and is the country's lead agency for development. As such, most Canadian organizations involved in international aid take their lead from CIDA. With an annual budget of $\$ 3.7$ billion and a mandate directly from the Parliament of Canada, CIDA is the largest player in international development in Canada and sets the direction for aid projects for all other aid organizations.

CIDA's ICT strategy includes programming that focuses on

- Using ICTs as tools for the development of the health and education sectors of developing countries.

- Building ICT capacity through support for policy and regulatory development.

- Using ICTs to support the sharing and exchange of knowledge.

CIDA also wants to promote strategic partnerships that focus on the collaboration among government, the private sector, and civil society to create opportunities for knowledge exchange as well as for bridging the digital divide. The primary goal of this approach is the reduction of poverty by providing access to information and knowledge through the use of ICTs. As it states in the document:

Poverty reduction is a central component of this strategy. Increasing equal access to, control of, and ability to derive benefits from socio-political and economic information can contribute to the reduction of poverty by providing individuals and communities with the opportunity to expand their choices and improve their livelihoods. The information can range from financially viable markets and income generating opportunities to the availability of government services and issues of governance to information on heath care and delivery, HIV/AIDS care/prevention, education and skills-development programs. (CIDA, 2006, p. i)

The document also emphasizes the important issues of the digital divide and gender inequality. It talks about the creation and use of indigenous knowledge and stresses the importance of capacity building to achieve sustainable development.

\section{Poverty}

Poverty is typically explained in economic terms as having little money or few material possessions. However, poverty is much more complex, referring also to an inability to access different types of capital, be they financial, human or physical (Sen, 1999). Furthermore, social and political aspects of poverty are key to understanding the developing-nation context of poverty. Writers in the field of international development cite no less than two dozen reasons why poverty still exists (Sen, 1999).

CIDA believes that ICTs contribute to the reduction in poverty by providing individuals with choice about which knowledge is valuable to them, including indigenous knowledge possessed by the poor and other traditionally disadvantaged groups, including women. However, throughout the document CIDA uses language steeped in economic, neoliberal, and globalization ideas. For example, the document in- 
cludes language such as, "Knowledge and information are therefore key factors in economic competitiveness and productivity, as well as in social and political development" (CIDA, 2006, p. 7). The question remains: economic competitiveness and productivity for whom? Most impoverished populations simply want to feed their families and lead fulfilling lives, whereas this language implies a larger economic calling. The concern is that this strategy may lead to the development of local industries to the betterment of local elite. Or worse, it may lead to the development of industry in developing countries to the betterment of populations in developed countries; hence fears of renewed colonialism.

At a Commonwealth Heads of Government Meetings (CHOGM) in Uganda, there were renewed calls for a reduction in trade barriers among developing countries but little call for a similar reduction in barriers among developed countries (Kisambira, 2007). This trade imbalance is of concern because international aid often benefits donor countries more than recipient countries (Kemp \& Kojima, 1985; Veltmeyer, 2005). Is the use of ICTs for development repeating the same pattern? If ICTs are deployed as outlined in the CIDA strategy, how will the trade imbalance as it exists now affect the intended development outcomes?

\section{Digital Divide}

CIDA recognizes that the digital divide is a significant barrier to any ICT projects in developing countries. The digital divide refers to the gap, both in terms of access and use, of ICTs. In the developing world, this divide can be exacerbated by a lack of reliable electricity, a lack of basic telecommunications infrastructure, and gender imbalances. In defining the digital divide, access in libraries, Internet cafés, or schools may have an increasing significance in the context of developing nations. As Sen (1999) and Smith (Campbell \& Skinner, 1976/1776) have noted, alleviating endemic poverty should have the goal of allowing people to appear in public without shame.

Another indicator of the digital divide is that most of the content exchanged over the Internet is in English, which less than 10 percent of the world's population understands (International Telecommunications Union [ITU], 2007). Also, the Internet population worldwide has been overwhelmingly male. This gap has been closed in developed countries as of 2005 and is rapidly being closed in some developing countries, like South Africa where 45 percent of Internet users are women (ITU, 2007). But it remains a significant issue in much of the world. Excluding women from access to ICTs immediately disenfranchises at least 50 percent of the world's populations from information and communications that they could use to benefit not only their lives but also the lives of their families and communities.

It is important to understand and resolve the digital divide because the divide prevents the equal sharing of knowledge, and knowledge is power. Hence power is not equally shared within developing countries, nor between developed and developing countries, creating an imbalance. And if education, particularly distance learning offered by Western education institutions, is to be carried out with such an imbalance, it will inevitably become a form of social and cultural colonialism.

CIDA (2006) proposes a "focus on pro-poor strategies emphasizing provision of rural infrastructure, access of women and the disenfranchised, capacity building and training as well as the creation and dissemination of local content in local languages" (p. 3 ). It then goes on to make sound suggestions for closing the digital divide, including using appropriate technologies (e.g., radio to disseminate information when computers are unavailable or impractical); using appropriate local content for local conditions; and targeting ICTs at roles that are traditionally female, including early childhood, health care, and education. However, CIDA (2006) also proposes "public-private partnerships to leverage private sector investors" (p. i) to bridge the divide, which clearly uses neoliberal language steeped in economic biases. This is reminiscent of Yang's (2003) suggestion to have ICT and higher education development be driven by good public policy rather than economic profit.

\section{Local-Versus-Global and Public- Versus-Private Control}

This paper calls for a renewed debate about globalversus-local and public-versus-private issues in international education. The pressures within a knowledge economy are overwhelmingly global; however, the effects of these pressures are usually local. Discourses 
often focus on public opportunities and spaces but manifest themselves in private spaces.

To its credit, CIDA's ICT strategy is a blend of the local and the global. In its policy directions on the digital divide, gender equity, and appropriate technology, CIDA espouses a local approach to introducing ICTs in developing countries. However, in implementation, CIDA calls for partnerships with global and private organizations to meet these local approaches. The global initiatives included the United Nations ICT Task Force, the G8 Digital Opportunities Task Force, the Markle Foundation, Accenture, and the United Nations Development Programme. The investment on ICT infrastructure falls squarely on private investment and innovation. The danger is that ICTs may become a way of empowering the rich in developing countries or simply furthering the interests of developed countries. And ICTs in education under CIDA's plan will be driven mostly by private, profit-driven interest.

Generally, public-private partnerships can be fruitful where appropriate. However, most developing countries do not have the infrastructures and capacities needed for these types of partnerships to be fruitful for both public and private interests. Recent experiences with the International Monetary Fund's Structural Adjustment Programs suggest that the public typically loses out in these partnerships (International Monetary Fund, 1998).

As laudable as CIDA's recognition of ICT infrastructure in rural areas and its attention to access for women and disadvantaged groups is, an emphasis on private investment can make things worse because the onus is on profits rather than good public policy. This creates pressure to place ICT infrastructure in areas where profits are more immediately realized (e.g., urban areas). This has the unintended effect of increasing brain drain from rural areas to urban areas. In regional economies like the Southern African Development Community (SADC), this brain drain becomes more acute as profits and people flow to larger, more established economies, notably South Africa (Landau \& Wa Kabwe Segatti, 2009).

\section{Capacity Building}

CIDA's strategy aims to develop local capacity so that development is sustainable and the benefits remain with the local populations. It strives to use ICTs and distance learning (with the help of ICTs) to enhance the delivery of education. Again, the public-versusprivate debate is a relevant one. Take Africa, for example: The number of higher education students in Africa has increased by more than 150 percent over the past two decades (World Bank, 2000). However, many universities in the region lack the public resources required to guarantee quality teaching and research (United Nations Educational, Scientific and Cultural Organization [UNESCO], 2007). Universities in Africa will not be able to meet the increasing demands without the immediate development of capacity in these areas. As noted in UNESCO's (2007) report on higher education in Africa:

The privatization and commercialization of higher education, as well as the proliferation of open and distance learning opportunities pose challenges. Responding to these effectively involves innovations not only in course provision to ensure relevancy, but also in revenue generation, quality assurance, institutional governance, and human resource management. At the same time, higher education institutions in Africa today must address a whole range of other issues, which include better access for certain groups such as women and the poor, intellectual property rights, research methodology, the brain drain, and the threat posed by HIV/AIDS. (para. 3)

ICTs, especially in infrastructures and services provided by the private sector alone, will not help much here. Capacity in the entire education system, as well as the capacity in the population's readiness to participate, should be the focus. And this cannot be done if the strategies ignore the development on the public side.

\section{Recommendations}

This paper encourages continuous debates about how ICTs are used in development and in international education. Developing nations must have the primary voice in these debates. The concern is simply that the less savory aspects of the knowledge economy and globalization have taken control of public policy, especially with respect to international higher education. This trend seems to move politics from the art of the 
possible to the practice of sound economic management. In doing so, public interest and the need for international education for public good will be lost.

This article concludes with four simple recommendations that governments can adopt to participate in the global economy with respect to ICTs in higher education without being steamrollered by more powerful influences and economies.

\section{Recommendation 1: Improve Access by Using Leapfrog Technologies}

Access to ICTs is no doubt the number one priority: access in terms of the availability of technologies, as well as the affordable cost (or no cost if poverty is the very issue) for the target populations. The current pattern of donating used hardware or software to developing nations is not a feasible solution. This only serves to dump Western garbage at the developing world's expense, and it does not really help the people or their communities. Moreover, this dumping of Western garbage creates a frustrating game of catchup, where developing nations are continually trying to keep pace with developed countries' older technology.

The UNESCO Forum on Higher Education, Research and Knowledge in 2004 recommended using leapfrog technologies (Hazelkorn, 2004). Leapfrog technologies mean that nations would leap ahead of current trends and embrace newer technologies; often ahead of developed nations. For example, in many developing nations, it is possible to buy a mobile phone in less than 24 hours, whereas renting a landline can take years. The next step is to leapfrog other ICTs, such as using wireless technologies to access the Internet instead of waiting for government and industry to install wired access. Not only is wireless access faster in terms of installation, but it is also more likely to be accessible in rural areas, where the majority of vulnerable populations live.

\section{Recommendation 2: Ensure Public Needs Are Met}

Although building ICT infrastructure may require private sector investment or public-private partnerships, it is important to keep in mind that the unintended consequences of such partnerships, including creating a digital divide or enabling brain drain, may occur as profit-driven projects dominate the development agenda. When it comes to ICTs in education, the consequences could mean the privatization of universities for the sole purpose of making profit. It could also mean a further divide between the rich and the poor. The question becomes whether turning higher education into a training ground for a knowledge-based economy is the whole picture. If not, what is the public good that ought to be protected, and what public service should national and international higher education provide?

Governments in both the donor countries and recipient countries have the responsibility to raise the debate in the public sphere. Incentives should be provided to ensure that public interests are looked after. For example, potential users of ICTs (especially women, children, and people living in rural areas) need to be involved at the earliest stages of ICT projects to determine what their needs, values, and capacities are with respect to ICTs. How could these people benefit from the technologies? Maybe they see it as most useful in contacting relatives in other jurisdictions. Maybe they would want to view local weather patterns to plant or harvest crops. The results of such a needs assessment will go a long way toward determining how any ICT projects should be implemented, as well as help local governments determine what sort of training and support will be needed. These issues should all be resolved before a single wire is connected, before a single computer is purchased, and before a single wireless signal is beamed.

\section{Recommendation 3: Use a Systemic and Evaluative Approach}

CIDA's strategy has recognized the need to address barriers embedded in social and cultural norms, such as gender inequality, age, and race. This is a step in the right direction. Even though the strategy focuses on using ICTs, programming aimed at addressing those barriers must also be in place. For instance, scholarships may be an effective solution in some places. But in extremely poor areas, providing direct financial assistance may not be effective because the family views a child as a valuable asset to earn an income or look after other members of the family. Sending him or her to school is neither a priority nor a possibility for the family. It may make more sense to design education 
programs that will allow the students to stay home to help out the family. This strategy has the added benefit of reversing brain drain and allowing students or graduates to transfer their knowledge in faster and more meaningful ways. It also serves to build capacity as local leaders and community members observe the changes in their own communities immediately and firsthand.

In addition to a systematic needs assessment, local leaders and government officials need to be involved at the earliest stages to determine how the project can most effectively be implemented and how success can be measured. This calls for an evaluative process developed at the beginning, rather than the end, of the project and should include the results of the public discussions that are part of the project conception and implementation. Evaluations of this nature should be done not only from the donor's point of view but also (or more importantly) from the user's point of view. Moreover, the evaluation and implementation plans need to fully account for the users' values and needs as identified in the planning of the programs.

This process of needs assessment, public discussion, implementation, and evaluation should be iterative rather than hierarchical, and it should continue past the life of the implementation project. Moreover, these processes should use already existing communications channels, including local newspapers, national radio systems, and local community meetings organized at either district council offices or schools.

\section{Recommendation 4: Focus on Peda- gogy}

ICTs in education have the potential to widen access and provide quality education. However, pedagogy needs to be at the heart of such efforts. It is a relatively simple matter to purchase ICTs for schools and universities and offer technical training via international donors. It is quite another to cultivate teachers' and students' ICT competencies to use the tools effectively for education. Cultivating these competencies and embedding them in the communities to make them useful requires a shift in values for the community members. These types of changes do not happen quickly or easily, requiring a concerted investment in time and care on the part of national governments, local leadership, and donor agencies.
For the past two decades, in developed countries progress has been made to integrate ICTs in teaching and learning. The benefits of technology-enhanced learning have just begun to emerge. Recently, the U.S. Department of Education (2009) released a report on online learning, concluding from thousands of empirical studies of learning outcomes that students in online learning perform better than those in traditional, face-to-face classrooms. The lessons learned from two decades of online learning may be applied to fast-track ICT integration in education in the developing world. But pedagogy is rooted in the social and cultural fabric of a nation. In that sense, development still needs to start locally to be meaningful for the affected populations.

A focus on pedagogy also means developing content in local languages using local curricula. Too often, international education falls into the import-export pattern of trade, where Western content in English is simply transported to the developing nation and students learn subjects that may or may not be relevant to their lives. A worse scenario is the brain drain when students attend Western universities but do not return to their communities after graduation. This is one of the greatest challenges in international education, because it speaks to the immense work in building capacity and sustainable development.

This calls for an ICT strategy to devote resources to pedagogy and provide incentives for Western institutions to partner with colleges or universities in developing countries where the needs are the greatest, not where the potential for profit is the greatest. Governments or agencies like CIDA should also provide incentives for content and curriculum development, with institutions from both the developed and developing countries being equal partners in this work. Developing nations must own the content and the process to create that content to build their capacity.

\section{Conclusion}

Educators now have an unprecedented opportunity to provide capacity, education, development, and economic growth to the world's poor using advanced information and communications technologies. These claims have, of course, been made before. Each new advance in technology has been heralded with claims that it would revolutionize education and solve all the 
world's problems. So it is with caution that I make any similar claim in this paper.

It is difficult to deny the speed of change ICTs bring to every aspect of modern life and the opportunities ICTs bring to education and development. These opportunities come with challenges and dangers, not the least of which is the danger of recreating the colonial mistakes of the past. Globalization, as it is construed through much of the world as economic dominance by Western powers, is certainly a danger and one that must be mitigated at the local level. Moreover, these challenges also come with costs and difficult questions about who benefits, who is harmed, and who controls the technology. These are deep policy questions that must be discussed and debated beginning at the local levels, where the technologies are hoped to make the largest effect.

There is always concern that ICTs are a waste of resources when people are starving, have no phones, and often have no electricity. Although these are genuine concerns, an investment in ICTs is not necessarily meant to help those populations in absolute poverty, except in indirect ways. ICTs are a cross-cutting phenomenon, so they have an effect across all sectors and therefore have the capacity to help all segments of a population. Moreover, ICTs help organizations that work with populations experiencing absolute poverty. ICTs are not, however, a panacea. It is important to use ICTs appropriately with respect to context, content, and language.

CIDA, through its strategy on the use of ICTs in developing countries, appears to recognize that ICTs are not a panacea to world poverty, but they have recognized them as a powerful tool that can affect all aspects of life in developing and developed countries. The concern is whether this power will be used for public good or private gain. Also, would this power result in global economic dominance or local capacity building? The answer is all of the above, thus renewing the call for more debate about the use of public versus private spaces as well as local versus global development.

Certainly the private sector and economic benefit are important drivers of development and need to be at the table during these debates and during the implementation of ICT projects. But they must not be allowed to dominate and control the process in nations that do not yet have the maturity to temper profitmotivated ICT projects.

Clearly there are wonderful opportunities for using ICTs in developing communities. Innovative use of leapfrog technologies, attention to public interests, systematic needs assessment and evaluation, and a strong focus on pedagogy will reshape the policy with regards to ICTs and international education and gear the development toward a meaningful change to all those who are involved.

\section{References}

Bacchi, C. (2000). Policy as discourse: What does it mean? Where does it get us? Discourse: Studies in the Cultural Politics of Education, 21(1), 45-57.

Bartz, D. (1990, June 23). Bells and banners welcome Mandela into Boston. The Associated Press.

Campbell, R. H., \& Skinner, A. S. (Eds.). (1976). Adam Smith: An inquiry into the nature and causes of the wealth of nations. Oxford: Clarendon Press. (Original work published 1776)

Canadian International Development Agency. (2006). CIDA's strategy on knowledge for development through information and communication technologies. Retrieved from http://wwwl.oecd.org/dac/ictcd/docs/matrixdocs/C AN_Cida_paperl.pdf

Carnoy, M., \& Rhoten, D. (2002). What does globalization mean for educational change? A comparative approach. Comparative Education Review, 46(1), 1-9.

Daniel, J. (2006). Technology in higher education: How to avoid failure and achieve success. Retrieved from http://www.col.org/colweb/site/pid/4101

Fraser, N. (1990). Rethinking the public sphere: A contribution to the critique of actually existing democracy. Social Text, 25/26, 56-80.

Freire, P. (1970). Pedagogy of the oppressed. New York: Continuum.

Hazelkorn, E. (2004, December). Accessing the knowledge society: Intended and unintended consequences of HE policy reviews. Forum on Higher Education, Research and Knowledge Colloquium on Research and Higher Education Policy, Paris, France: United Nations Educational, Scientific and Cultural Organization. 
Hillman, A. L. (2002). The World Bank and the persistence of poverty in poor countries. Europäische Zeitschrift für politische Ökonomie, 18(4), 783.

International Monetary Fund. (1998). Report of the group of independent persons appointed to conduct an evaluation of certain aspects of the enhanced structural adjustment facility. Retrieved from http://www.imf.org/external/pubs/ft/extev/esaf2.pdf

International Telecommunications Union. (2007). Millennium development goals. Retrieved from http://www.itu.int/ITU-D/ict/mdg/

Kemp, M. C., \& Kojima, S. (1985). Tied aid and the paradoxes of donor-enrichment and recipientimpoverishment. International Economic Review, 26(3), 721-729.

Kisambira, E. (2007, November 26). Uganda: Commonwealth urged to break trade barriers. East African Business Week (Kampala). Retrieved from: http://allafrica.com/stories/200711261760.html

Landau, L. B., \& Wa Kabwe Segatti, A. (2009). Human development impacts of migration: South Africa case study. Retrieved from http://mpra.ub.unimuenchen.de/19182/1/MPRA_paper_19182.pdf

Monash University. (2007). What is international education? Retrieved

http://www.education.monash.edu.au/centres/mcrie /whatis.html

Peters, M. (2001). National education policy constructions of the 'knowledge economy': Towards a critique. Journal of Educational Enquiry, 2(1), 1-22.

Sen, A. (1999). Development as freedom. New York: Knopf.

U.S. Department of Education. (2009). Evaluation of evidence-based practices in online learning: A meta-analysis and review of online learning studies. Retrieved from http://www.ed.gov/rschstat/eval/tech/evidencebased-practices/finalreport.pdf
United Nations Educational, Scientific and Cultural Organization. (2007). Higher education in Africa. Retrieved from http://portal.unesco.org/education/en/ev.phpURL_ID\%3D31028\&URL_DO\%3DDO_TOPIC\&U RL_SECTION\%3D201.html

Veltmeyer, H. (2005). Development and globalization as imperialism. Canadian Journal of Development Studies, 26(1), 89-106.

Waters, M. (1995). Globalisation. New York: Routledge.

World Bank (1995). Priorities and Strategies for Education. Washington, DC: World Bank.

World Bank. (2000). Higher education in developing countries: Peril and promise. Washington, DC: World Bank.

World Bank. (2007). Education for the knowledge economy. Retrieved from http://go.worldbank.org/I8T7C0VPV0

Yang, R. (2003). Globalisation and higher education development: A critical analysis. International Review of Education, 49(3-4), 269-291.

IJEPL is a joint publication of the Association for Supervision and Curriculum Development, the Faculty of Education at Simon Fraser University, and the College of Education and Human Development at George Mason University. By virtue of their appearance in this open access journal, articles are free to use, with proper attribution, in educational and other non-commercial settings 90 days after initial publication. Copyright for articles published in IJEPL is retained by the authors. More information is available on the IJEPL Web site: http://www.ijepl.org 